\title{
Assessment of the Level and Health Risk of Fluoride and Heavy Metals in Commercial Toothpastes in Bangladesh
}

\author{
Chanchal Chayan Paul', Md. Abu Shamim Khan², Probir Kumar Sarkar', Abdul Hakim², \\ Md. Waliullah ${ }^{2}$, and Bablu Hira Mandal ${ }^{3, *}$ \\ ${ }^{1}$ Department of Chemical Engineering, Jashore University of Science and Technology, Jashore-7408, Bangladesh \\ ${ }^{2}$ Environmental Laboratory, Asia Arsenic Network, Jashore, Bangladesh \\ ${ }^{3}$ Department of Chemistry, Jashore University of Science and Technology, Jashore-7408, Bangladesh
}

\section{* Corresponding author:}

tel: $+880-1711013881$

email:bhiramandal@gmail.com

Received: February 10, 2019

Accepted: August 1, 2019

DOI: $10.22146 /$ ijc.43266

\begin{abstract}
Toothpaste is one of the daily essentials, and good quality control practices over it are very important to protect the oral public health from adverse effects. The current study aimed to assess the concentration of fluoride and heavy metals, physicochemical properties in ten different toothpaste samples in Bangladesh, followed by related health risk analysis. $\mathrm{pH}$, moisture content, $\mathrm{F}^{-}, \mathrm{As}, \mathrm{Cu}, \mathrm{Pb}$ contents were measured by membrane electrode, thermogravimetric, SPADNS, HG-AAS, flame-AAS methods, respectively. The results were compared to the specification of the packet and Bangladesh Standard and Testing Institute (BSTI) standard. The physicochemical properties wellmatched the formulation standard values. The moisture content was $27.18 \pm 2.20$ to 52.10 $\pm 5.01 \%$, with $50 \%$ of the samples in permissible limit but the $\mathrm{pH}$ of all the samples (6.408.60) was within the standard limit. Available $\mathrm{F}^{-}, \mathrm{Cu}, \mathrm{Pb}$, and As content ranged from $803-1617,2.78-13.10,0.27-2.12$, and $0.027-0.637 \mathrm{mg} / \mathrm{Kg}$, respectively. $\mathrm{F}^{-}$content in $80 \%$ toothpaste did not meet the packet specification and was higher than BSTI standard, though heavy metals were within the BSTI limit. Hazard quotient (HQ) and HI (Hazard Index) analysis revealed that toothpaste safe from heavy metal related to health risk.
\end{abstract}

Keywords: toothpaste; fluoride; heavy metals; health risk

\section{- INTRODUCTION}

Toothpaste is absolutely necessary for our daily oral hygiene routine. It is used for cleaning and polishing the surface of teeth to remove dental plaque formed on teeth and gums as well as it prevents from the most common oral disease like dental cavities and periodontal usually caused by bacteria in the mouth [1]. Principal ingredients in toothpaste formulations are polishing agents, binding agents, foaming agents, flavoring agents, humectants, and water [2]. In modern toothpaste, sodium fluoride or monofluorophosphate is added as anticaries agents because fluoride is widely believed to prevent dental decays [3]. However, various studies have shown that excessive fluoride $\left(\mathrm{F}^{-}\right)$intake causes fluorosis, cancer, arthritis and it has also been linked to symptoms of stomach pain and indigestion [4-7]. It is an additional source to other different means (polluted air, water, and the food chain) of entering excessive amounts of fluoride in the form of various compounds into the human body [8]. There are several previous reports which claimed questionable anti-caries effectiveness of commercial toothpaste as a result of lack of free available fluoride or inhomogeneity in total and free fluoride concentrations of toothpaste [9-10]. Thus, research and monitoring of the fluoride contents in commercial toothpaste in many parts of the world have got interested [11-18]. In addition to fluoride content, physicochemical and microbial properties of the toothpaste are also very important for oral health [19-20].

On the other hand, heavy metals are regarded as micropollutants since their excess presence has an adverse effect both on health and the environment. 
However, their occurrence in nature is not harmful to our environment as they are present only in very small amounts [21-22]. They have gained significant importance due to their persistence, high toxicity, and bioaccumulation properties. Heavy metals like lead, arsenic, copper, cadmium, mercury have been proved to have a negative impact on human health and their chronic toxicity to humans is associated with many chronic diseases like mental disorders, hypertension, pneumonia, gastrointestinal disorders, vascular disease, coronary heart disease, myocardial infarction, central nervous functions, kidney disorder and cancer [23-24]. They can be exposed through direct and indirect sources like drinking water [5,22], food [25-26], air [27-28], soil [2930] and body care products [6,31-33]. Besides the reports on the evaluation of the possible contact and adverse health effects of the heavy metals from traditionally regulated sources, the exposure to metal toxins from toothpaste and mouthwashes have also gained importance in the recent years [6-7,10-12,18-21,34]. However, the investigation on toothpaste or oral care products remained comparatively ignored and needs more study especially in developing countries like Bangladesh.

As far as we know, there are still no evaluation reports on the toothpaste and mouthwashes available in the markets of Bangladesh. Therefore, we have aimed to assess some physicochemical properties, concentrations of fluoride ion, and heavy metals $(\mathrm{Cu}, \mathrm{As}$, and $\mathrm{Pb})$ in different commercial kinds of toothpaste available in the local markets in Bangladesh and the related potential health risk. Eventually, this study will help to find an idea about these products, which will help to build up awareness of good quality control over the toothpaste to protect public oral health.

\section{- EXPERIMENTAL SECTION}

\section{Materials}

All reagents were of analytical grade like Nitric acid (Merck, Germany), Hydrochloric acid (Merck, Germany), Sodium Borohydride (Organic, Belgium), Potassium Iodide (Kanto, Japan), while deionized water used for the preparation of all solutions were stored in polyethylene bottles. SPADNS reagent, fluoride, metals, and buffer standards were purchased from $\mathrm{HACH}$, USA.

\section{Instrumentation}

The electric oven (Digi system, Taiwan) was used for drying. $\mathrm{pH}$ was measured with HACH sensION 156 Multi-Parameter Meter, USA, while fluoride was determined with DR/2010 Spectrophotometer, HACH, USA. Heavy metals were estimated with an atomic absorption spectrophotometer (AA-6200, Shimadzu, Japan).

\section{Procedure}

\section{Sample collection}

A total of 10 widely used toothpaste samples of different brands were collected from local markets of the Jashore city in Bangladesh and labeled TP-1 to TP-10. Among these samples five (TP-1-5) were general, one medicated (TP-6), two herbal (TP-7 and 8), and two were baby toothpaste (TP-9 and 10) (Table1). The samples

Table 1. List of toothpaste samples along with their category, chemical formulation, and color

\begin{tabular}{lllll}
\hline Sample ID. & Brand name & Category & Chemical formulation & Color \\
\hline TP-1 & Pepsodent & General & Cream & White \\
TP-2 & Close up & General & Gel & Green \\
TP-3 & White plus & General & Cream & White \\
TP-4 & Fresh gel & General & Gel & Green \\
TP-5 & Colgate active salt & General & Cream & Blue \\
TP-6 & Medi plus & Medicated & Cream & White \\
TP-7 & Pepsodent herbal & Herbal & Cream & Light Green \\
TP-8 & Colgate herbal & Herbal & Cream & White \\
TP-9 & Meril baby & Baby & Gel & Red \\
TP-10 & Kodomo & Baby & Cream & White \\
\hline
\end{tabular}

Chanchal Chayan Paul et al. 
were properly checked for their physical appearance, name of the manufacturer, batch number, and manufacturing date, expiry date, manufacturing license number, testing board seal, and dental foundation seal at the time of purchase.

\section{Sample preparation}

Ten grams of raw samples were oven-dried at $105^{\circ} \mathrm{C}$ until a constant weight was obtained on cooling in a desiccator. Toothpaste samples ( $1 \mathrm{~g}$ each) were soaked in a $250 \mathrm{~mL}$ glass beaker with $100 \mathrm{~mL}$ water for $24 \mathrm{~h}$. The mixture was filtered into the $100 \mathrm{~mL}$ volumetric flask through Whatman-1 filter paper, the residue was washed thoroughly, and the filtrate was made up to volume with deionized water [35-36].

\section{The homogeneity test}

To test the homogeneity of the toothpaste samples, the normal force was applied at the crimped end of the tube at room temperature, and the nature extrusion of paste from the collapsible tube was observed [36-37].

\section{Determination of gritty matter}

A small amount of each toothpaste sample was rubbed with a finger for about 15 to $20 \mathrm{~cm}$ long on a butter paper. The number and intensity of scratches that appeared on the butter paper were judged for the presence of solid particles [36-37].

\section{Determination of fineness}

The toothpaste samples were checked on two standard sieves of 150 and 75 microns. For this, $50 \mathrm{~mL}$ of water was added into $10 \mathrm{~g}$ of toothpaste in a $100 \mathrm{~mL}$ beaker. The mixture was stirred occasionally for 30 min until the toothpaste was completely dispersed and was passed through sieves. Then the sieve was washed with running tap water until all the soluble matters passed through the sieves. The residue retained on sieves was collected and dried in an oven at $105^{\circ} \mathrm{C}$. The dried residue was weighed, and the fineness was calculated with the Eq.

(1) [37]:

$\%$ Mass $=\frac{M_{1}}{M} \times 100$

where, $M_{1}=$ Mass of residue retained on the sieve (g); M $=$ Mass of material taken for the test $(\mathrm{g})$.

\section{Determination of spreadability}

A dry and clean glass plate $(10 \mathrm{~cm} \times 10 \mathrm{~cm})$ was taken, and $1 \mathrm{~g}$ of sample was kept at the center of the plate. Another glass plate was carefully placed over it. To avoid the sliding of the plate's $2 \mathrm{Kg}$ weight was placed above the glass plates at the center and allowed for $30 \mathrm{~min}$. The diameter of the spreading paste was measured in centimeters [36].

\section{Determination of foaming power}

In a typical process, $5 \mathrm{~g}$ of toothpaste sample was taken in a glass beaker $(100 \mathrm{~mL})$, and $10 \mathrm{~mL}$ of water was added into it, which was kept for $30 \mathrm{~min}$ for complete dispersion. The volume was adjusted to $50 \mathrm{~mL}$ by adding sufficient water. The mixture was then was transferred to a $250 \mathrm{~mL}$ measuring cylinder. It was ensured that no residue was left in the beaker, no foam was formed, and no lump paste was transferred during the transfer of slurry into a measuring cylinder. A uniform suspension was also confirmed at a temperature of $30{ }^{\circ} \mathrm{C}$. The stoppered cylinder was given 12 complete shakes and was allowed to stand for $5 \mathrm{~min}$. The volume of foam with water and water only were recorded. Foaming power was calculated using the Eq. (2) [36].

Foa ming power $=\mathrm{V}_{1}-\mathrm{V}_{2}$

where, $\mathrm{V}_{1}=$ Volume of foam with water $(\mathrm{mL}) ; \mathrm{V}_{2}=$ Volume of water only $(\mathrm{mL})$.

\section{Moisture content estimation}

For moisture content analysis, $10 \mathrm{~g}$ of sample was taken in a pre-weighted glass dish and put it in an electric oven to dry it at $105{ }^{\circ} \mathrm{C}$ for $24 \mathrm{~h}$. The dried sample was taken in desiccators for cooling, and the weight of the dried sample was taken by the electric balance. Moisture contents were calculated from the differences between the weight of the raw wet sample and the oven-dried sample using the Eq. (3) [35-36].

$\%$ moisture $=\frac{\left(\mathrm{w}_{1}-\mathrm{w}_{2}\right) \times 100}{\mathrm{w}_{1}}$

where, $\mathrm{w}_{1}=$ weight toothpaste $(\mathrm{g}) ; \mathrm{w}_{2}=$ weight of raw dried toothpaste (g).

\section{pH measurement}

$\mathrm{pH}$ was measured by the membrane electrode 
method in $1 \%(\mathrm{w} / \mathrm{v})$ aqueous suspension of each toothpaste and de-ionized water with a $\mathrm{pH}$ meter [35-36].

\section{Fluoride estimation}

In this process, $10 \mathrm{~mL}$ of sample was taken in a test tube, and $2.00 \mathrm{~mL}$ of SPADNS reagent was added into it for color development. The pink color was developed and absorbance was measured by UV-VIS spectrophotometer (HACH, DR/2010, USA) at $570 \mathrm{~nm}$ [35-36]. Before measurement, the UV-Vis spectrophotometer was calibrated by the fluoride ion reference solution.

\section{Heavy metals estimation}

The heavy metals in toothpaste were analyzed by atomic absorption spectrophotometer using flame-AAS method for copper and lead, and HG-AAS methods for As [36-38]. In brief, $5 \mathrm{~g}$ of dried toothpaste sample was digested with concentrated nitric acid and $30 \%$ hydrogen peroxide at $95{ }^{\circ} \mathrm{C}$ following USEPA guidelines [38]. A solution of $100 \mathrm{~mL}$ was prepared with necessary dilution with dilute nitric acid and distilled water. The metal content by mass of sample $(\mathrm{mg} / \mathrm{Kg})$ was calculated automatically by the instrument and manually with the Eq. (4).

Metal concentration $(\mathrm{mg} / \mathrm{Kg})=\frac{(\mathrm{A}-\mathrm{B}) \mathrm{C}}{\mathrm{D}}$

where, $\mathrm{A}=$ concentration of metal in sample, as determined by AAS; $\mathrm{B}=$ concentration of the metal found in blank $(\mathrm{mg} / \mathrm{L}) ; \mathrm{C}=$ volume of extract $(\mathrm{mL}) ; \mathrm{D}=$ weight of sample $(\mathrm{Kg})$.

\section{Data analysis}

The experimental data were analyzed with SPSS software. Daily intake of fluoride and heavy metals $(\mathrm{Cu}$, $\mathrm{Pb}$, and $\mathrm{As}$ ), Hazard Quotients (HQ) and Hazard Index(HI)were calculated using the Eq. (5-7) [37-38].

Daily Intake, DI $(\mathrm{mg} / \mathrm{Kg} /$ day $)=\frac{\mathrm{C}_{\mathrm{i}} \times \mathrm{D}_{\text {int ake }}}{\mathrm{B}_{\text {weight }}}$

where, $C_{i}=$ Concentration of ' $i$ ' in sample taken for analysis (in $\mathrm{mg} / \mathrm{Kg}$ ); $D_{\text {intake }}=$ the daily intake of toothpaste $(0.264 \mathrm{~g} /$ person/day $) ; B_{\text {weight }}=$ the body weight $(60 \mathrm{Kg}$ in this study).

Hazarad Quotient, $H Q=\frac{D I}{R_{f} D}$

where, $\mathrm{DI}=$ Daily intake $(\mathrm{mg} / \mathrm{Kg} /$ day $) ; \mathrm{R}_{\mathrm{f}} \mathrm{D}=$ Oral Reference Dose $(\mathrm{mg} / \mathrm{Kg} /$ day); Oral Reference Dose $\left(\mathrm{mg} / \mathrm{Kg} /\right.$ day) for $\mathrm{F}, \mathrm{Cu}, \mathrm{Pb}$ and As are $6.0 \times 10^{-2}, 4.0 \times$ $10^{-2}, 4.0 \times 10^{-3}, 3.0 \times 10^{-4}$.

Hazard Index, $\mathrm{Hi}=\sum_{\mathrm{i}}^{4} \mathrm{HQi}$

where, $\mathrm{HI}=$ Hazard Index; $\mathrm{HQ}_{\mathrm{i}}=$ Hazard Quotient.

\section{- RESULTS AND DISCUSSION}

Ten most widely used toothpaste samples were analyzed following standard methods [36]. From the results of physical parameters (Table 2), all the kinds of toothpaste were found to be homogeneous, i.e., they released from the collapsible tube in the form of a homogeneous mass at room temperature, indicating no toothpaste solidified out of the tube and too thin to be

Table 2. Physical parameters study data

\begin{tabular}{cclcccc}
\hline \multirow{2}{*}{$\begin{array}{c}\text { Sample } \\
\text { ID }\end{array}$} & $\begin{array}{c}\text { Spreadability } \\
(\mathrm{cm})\end{array}$ & Gritty Matter & $\begin{array}{c}\text { Foaming } \\
\text { Power }(\mathrm{mL})\end{array}$ & Homogeneity & \multicolumn{2}{c}{ Fineness } \\
\cline { 6 - 7 } & & & & & 150-micron & $\begin{array}{c}75 \text {-micron } \\
\text { sieve }\end{array}$ \\
TP-1 & 7.75 & Absent & 65 & Homogeneous & 0.30 & 1.38 \\
TP-2 & 6.50 & Absent & 53 & Homogeneous & 0.23 & 1.22 \\
TP-3 & 7.91 & Absent & 54 & Homogeneous & 0.21 & 1.14 \\
TP-4 & 7.45 & Few granular & 58 & Homogeneous & 0.35 & 1.65 \\
TP-5 & 7.34 & Few granular & 70 & Homogeneous & 0.26 & 1.32 \\
TP-6 & 9.33 & Absent & 55 & Homogeneous & 0.18 & 1.07 \\
TP-7 & 7.38 & Absent & 72 & Homogeneous & 0.22 & 1.12 \\
TP-8 & 6.95 & Absent & 74 & Homogeneous & 0.31 & 1.43 \\
TP-9 & 8.25 & Absent & 51 & Homogeneous & 0.11 & 0.85 \\
TP-10 & 7.89 & Absent & 52 & Homogeneous & 0.16 & 0.96 \\
\hline
\end{tabular}

Chanchal Chayan Paul et al. 
held in the tube. The samples were also free from hard and sharp-edged abrasive particles, i.e., the ingredients added to these toothpastes were grounded properly and uniformly mixed. So, the toothpaste samples are safe for the gums and enamel since the regular use of toothpaste with gritty matters may wear off the teeth in the long run. According to the BSTI standard, the maximum particles retained on the sieve is $0.5 \%$ by mass for 150 microns and $2.0 \%$ by mass for 75 microns [36]. The fineness of the toothpastes varied from $0.11-0.35 \%(\mathrm{w} / \mathrm{w})$ and $0.85-1.85 \%$ $(\mathrm{w} / \mathrm{w})$ for 150 and 75 -micron sieve, respectively (Table 2), which satisfied the BSTI standards. It is also inferred that there were no coarse particles in the toothpaste which may cause scratching on the enamel surface.

The spreadability of the samples $(6.50-9.33 \mathrm{~cm})$ was within the standard value (maximum $8.5 \mathrm{~cm}$ ) except sample no. TP-6 (Table 2) [36]. Thus, there was no difficulty in the filling and extrusion of toothpaste from the tubes. In the case of the foam formation, all the toothpastes revealed the standard foam formation (minimum $50 \mathrm{~mL}$ ), ranged from $51-74 \mathrm{~mL}$, and indicated sufficient cleansing action in terms of the foam formation property.

The obtained results for moisture contents, $\mathrm{pH}$ values, fluoride, and heavy metals content (Table 3) were compared with the specification of the packets and BSTI standard [36]. Moisture content prevents toothpaste from hardening on exposure to air during storage and preservation. The average moisture content found in toothpaste samples was $35.26 \%$, which matched with standard values (35\%). However, $50 \%$ of the samples had higher values and the rest $50 \%$ had below the standard value. Maximum and minimum moisture contents observed were $52.10 \pm 5.01 \%$ and $27.18 \pm 2.20 \%$ in TP10 and TP-4, which were specialized for children and gel type toothpaste, respectively (Table 3 ). The $\mathrm{pH}$ value indicates the inorganic constituents in toothpaste. Acidic $\mathrm{pH}$ encourages the growth of mouth bacteria that causes dental caries [4]. The average $\mathrm{pH}$ of toothpaste samples was detected 7.52 which is within BSTI standard (6.50 to 10.50 ). The maximum and minimum $\mathrm{pH}$ was found $8.60 \pm 0.40$ and $6.40 \pm 0.28$ in Tp- 6 and TP-4. Fifty percent of the samples were nearly neutral $\mathrm{pH}$, and $50 \%$ of the samples were slightly alkaline. Thus the toothpaste having alkaline $\mathrm{pH}$ value contain inorganic ingredients like calcium carbonate and phosphate, and the neutral values are silica-based [10].

Fluoride is believed to prevent tooth decay and most of the dental diseases [3]. So, the fluoride level determines the activity, potency, and commercial acceptability of toothpaste $[36,39]$. The average fluoride concentration in the samples was $1251.03 \mathrm{mg} / \mathrm{Kg}$, which is greater than the maximum recommended value $(1000 \mathrm{mg} / \mathrm{Kg})$ [37]. Only one sample (TP-1) contained the tolerable fluoride concentration and another one (TP-10) sample below the

Table 3. Moisture content, $\mathrm{pH}, \mathrm{F}^{-}, \mathrm{Cu}, \mathrm{Pb}$ and As content

\begin{tabular}{lcccccc}
\hline \multirow{2}{*}{ Sample ID } & $\begin{array}{c}\text { Moisture } \\
\text { content }(\%)\end{array}$ & $\mathrm{pH}$ & $\begin{array}{c}\text { Conc. of } \mathrm{F}^{-} \\
(\mathrm{mg} / \mathrm{Kg})\end{array}$ & \multicolumn{2}{c}{ Conc. of Heavy Metals $(\mathrm{mg} / \mathrm{Kg})$} \\
\cline { 5 - 7 } TP-1 & $36.51 \pm 5.22$ & $8.15 \pm 0.32$ & $1000.12 \pm 52.09$ & $4.64 \pm 0.78$ & $0.88 \pm 0.09$ & $0.044 \pm 0.02$ \\
TP-2 & $32.08 \pm 3.51$ & $7.12 \pm 0.13$ & $1351.21 \pm 24.69$ & $4.26 \pm 0.59$ & $0.77 \pm 0.10$ & $0.085 \pm 0.03$ \\
TP-3 & $28.16 \pm 4.62$ & $8.33 \pm 0.21$ & $1169.02 \pm 40.12$ & $2.78 \pm 0.48$ & $0.27 \pm 0.03$ & $0.027 \pm 0.01$ \\
TP-4 & $27.18 \pm 2.20$ & $6.40 \pm 0.28$ & $1427.65 \pm 33.12$ & $5.63 \pm 1.02$ & $1.34 \pm 0.12$ & $0.224 \pm 0.08$ \\
TP-5 & $39.80 \pm 4.10$ & $6.93 \pm 0.15$ & $1617.33 \pm 51.20$ & $5.38 \pm 0.96$ & $1.27 \pm 0.15$ & $0.153 \pm 0.05$ \\
TP-6 & $36.05 \pm 4.25$ & $8.60 \pm 0.40$ & $1298.18 \pm 46.23$ & $13.10 \pm 1.68$ & $2.12 \pm 0.26$ & $0.637 \pm 0.12$ \\
TP-7 & $37.56 \pm 3.82$ & $8.23 \pm 0.28$ & $1446.51 \pm 36.21$ & $5.02 \pm 1.12$ & $1.23 \pm 0.22$ & $0.098 \pm 0.04$ \\
TP-8 & $32.63 \pm 2.69$ & $8.38 \pm 0.35$ & $1355.12 \pm 25.32$ & $4.49 \pm 0.51$ & $0.34 \pm 0.01$ & $0.183 \pm 0.07$ \\
TP-9 & $30.54 \pm 2.58$ & $6.42 \pm 0.46$ & $1042.08 \pm 41.25$ & $4.37 \pm 0.39$ & $0.98 \pm 0.10$ & $0.042 \pm 0.01$ \\
TP-10 & $52.10 \pm 5.01$ & $6.60 \pm 0.52$ & $803.08 \pm 20.13$ & $3.71 \pm 0.88$ & $0.57 \pm 0.06$ & $0.076 \pm 0.03$ \\
Maximum & 52.10 & 8.60 & 1617.33 & 13.10 & 2.12 & 0.64 \\
Minimum & 27.18 & 6.40 & 803.08 & 2.78 & 0.27 & 0.03 \\
Average & 35.26 & 7.52 & 1251.03 & 5.34 & 0.98 & 0.16
\end{tabular}


permissible range, while $80 \%$ of the samples exceeded the BSTI level. The highest concentration of fluoride ion, $1617 \pm 51.20 \mathrm{mg} / \mathrm{Kg}$, was detected in sample TP-5, which is a medicated toothpaste. The least concentration, $803 \pm$ $20.13 \mathrm{mg} / \mathrm{Kg}$, was in the sample TP-10 which was the special toothpaste for children (Table 3). Two pediatric types of toothpaste (TP-9 and TP-10) contained $1042 \pm$ $41.25 \mathrm{mg} / \mathrm{Kg}$ and $803.08 \pm 20.13 \mathrm{mg} / \mathrm{Kg}$ fluoride ion, respectively. However, the recommended permissible limit for fluoride in pediatric toothpaste is $425-625 \mathrm{mg} / \mathrm{Kg}$, and for adults is $825-1250 \mathrm{mg} / \mathrm{Kg}$ [36,40-41]. Hence, both of the baby toothpaste contained excess fluoride concentration, and $70 \%$ of the adult toothpaste samples contained higher fluoride, which can be a threat to oral health [6-7].

Fluoride toothpaste is recommended to be more effective in preventing tooth decay at higher fluoride concentrations. Nevertheless, excess fluoride ion $(>1000 \mathrm{mg} / \mathrm{Kg}$ ) could cause tooth enamel decay, skeletal fluorosis, abdominal pain, excessive saliva, nausea, vomiting, seizures and muscle spasms, death due to respiratory paralysis [10-12,40-41]. In addition, being an endocrine disrupter higher fluoride concentration can affect the bones, brain, thyroid gland, pineal gland, and even the blood sugar levels [7,40]. Therefore, the high fluoride concentrations measured in the adult toothpaste pose a serious health concern. However, if fluoride is ingested during the development of the tooth, it resists the attacks of acids on the enamel in the future [41]. Hence, the concentration of fluoride in the pediatric toothpaste (TP-9 and 10) may be beneficial to children. It is interesting to observe that some of the toothpaste did not mention the maximum fluoride content on the packet level. This means the fluoride concentration has not been properly checked for those samples.

On the other hand, the samples having packet leveling, simply mentioned the maximum fluoride content $1000 \mathrm{mg} / \mathrm{Kg}$ instead of the exact concentration. Unfortunately, almost none of them meet their demand rather contained excess fluoride. As a result, the use of these kinds of toothpaste may create a threat to public health.

Heavy metals are considered as mere contaminants for toothpaste as their roles are not clearly defined in the toothpaste formulation. However, their presence in the toothpaste may be accounted for abrasives, materials used from the plant sources [42-43], accidental crosscontamination during processing, and the deliberate introduction of metals as therapeutic ingredients for more efficacy [43]. Consequently, these metals may become harmful when they are ingested above the tolerance level, and daily use may have a significant adverse health effect.

Table 3 represents the concentration of arsenic, copper, and lead in different toothpaste samples. The average concentration of arsenic, copper, and lead was $0.16,5.34$ and $0.98 \mathrm{mg} / \mathrm{Kg}$, respectively, which are within the permissible range for toothpaste. However, the average concentration of As exceeded the threshold value $(\max 0.05 \mathrm{mg} / \mathrm{Kg}$ ) for drinking water [40]. The maximum concentration of arsenic, copper, and lead was found $0.637 \pm 0.12,13.10 \pm 1.68$, and $2.12 \pm 0.26$ $\mathrm{mg} / \mathrm{Kg}$ in TP-06, which are higher than USEPA standard as well as BSTI $[36,39]$. The higher level may be due to the coloring active salt contents in creamy toothpaste. On the other hand, the minimum concentration of arsenic, copper, and lead was detected $0.27 \pm 0.01,2.78$ \pm 0.48 and $0.27 \pm 0.03 \mathrm{mg} / \mathrm{Kg}$ in TP-03, a white creamy toothpaste, which satisfies the USEPA standard [38-39]. It is surprising to note that the presence of these heavy metals in the specification on the labeling of the packets was not mentioned in any of the samples. This should be mentioned since the excess presence of these heavy metals may be toxic to human health [36].

The Pearson correlation indicates positive correlation among the metals present in the toothpaste samples, having $\mathrm{R}^{2}$ value for $\mathrm{Pb}$ and $\mathrm{As}, \mathrm{Pb}$ and $\mathrm{Cu}$, and $\mathrm{Cu}$ and As are 0.5990, 0.7537, and 0.9345, respectively (Fig. 1-3). So, these metals might have been incorporated in toothpaste from the same sources.

Table 4 shows the acceptable upper limit (UP) of $\mathrm{Pb}, \mathrm{Cu}, \mathrm{As}$, and $\mathrm{F}^{-}[40]$ whereas, Fig. 4 and 5 represent the fluoride, and the metals intake through the daily intake of toothpaste. It is seen that in $90 \%$ of toothpaste samples, the daily intake of fluoride is greater than the tolerable upper limit of daily intake (UL). However, the value is very high in the baby toothpaste (TP-9 and 10), which may cause fluorosis in the long run [38]. 
Since these metals are considered as potentially carcinogenic substances [39-40], the potential health risk from fluoride, $\mathrm{Cu}, \mathrm{Pd}$, and $\mathrm{As}$, was assessed with the related parameter, Hazard quotient (HQ) and Hazard Index (HI) (Table 5). Hazard quotient was estimated using oral

Table 4. Tolerable Upper Limit (UL) for investigated element [40]

\begin{tabular}{|c|c|}
\hline Element & $\mathrm{UL}$ (mg/day) \\
\hline $\mathrm{Pb}$ & 0.240 \\
\hline $\mathrm{Cu}$ & 10.00 \\
\hline As & 0.01 \\
\hline $\mathrm{F}^{-}$ & $4.00,1.00-2.20^{*}$ \\
\hline
\end{tabular}

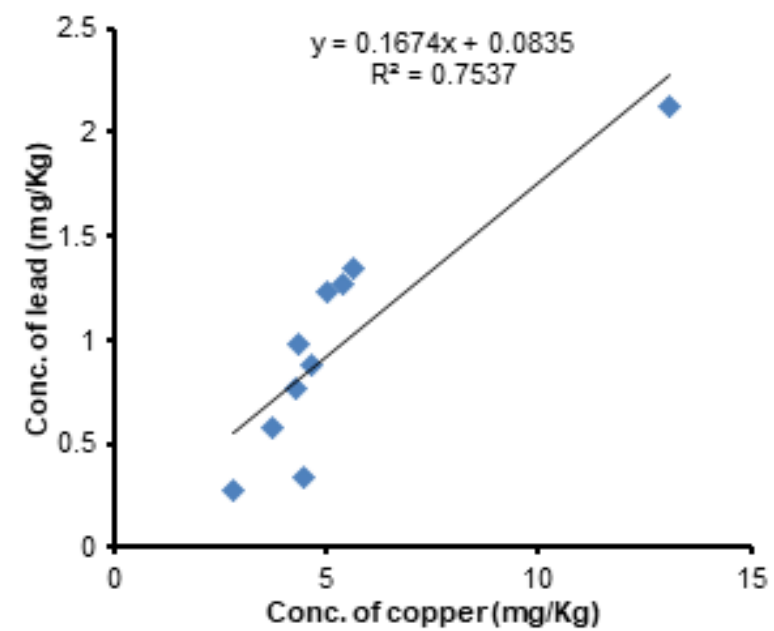

Fig 2. Correlation chart of $\mathrm{Cu}$ and $\mathrm{Pb}$

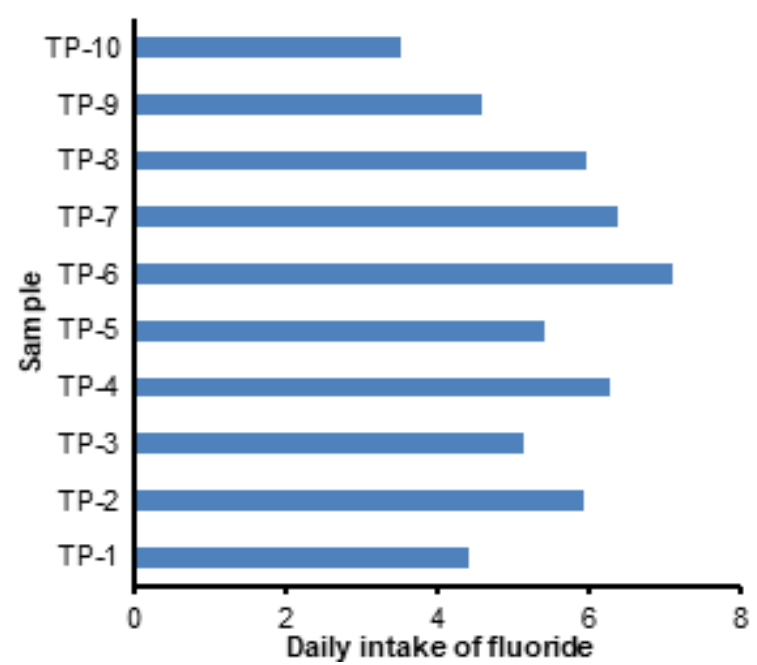

Fig 4. Daily intake of fluoride

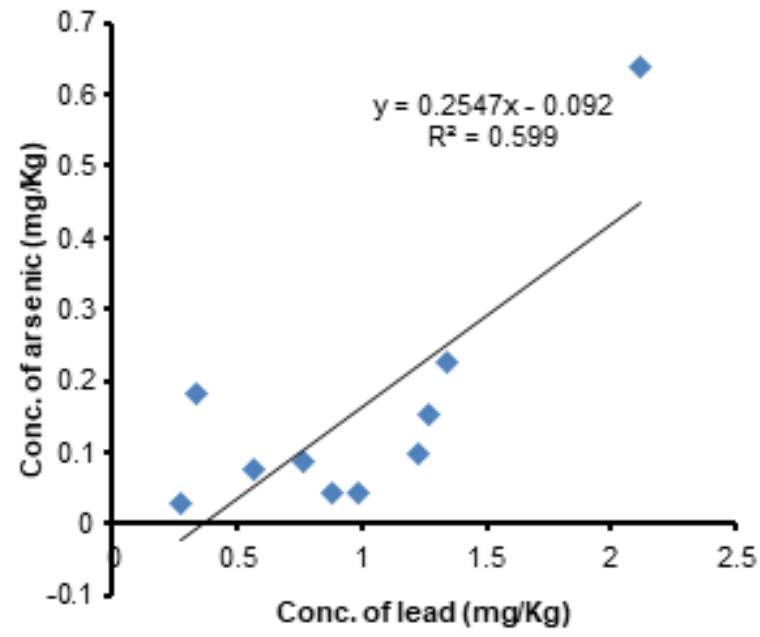

Fig 1. Correlation chart of $\mathrm{Pb}$ and $\mathrm{As}$

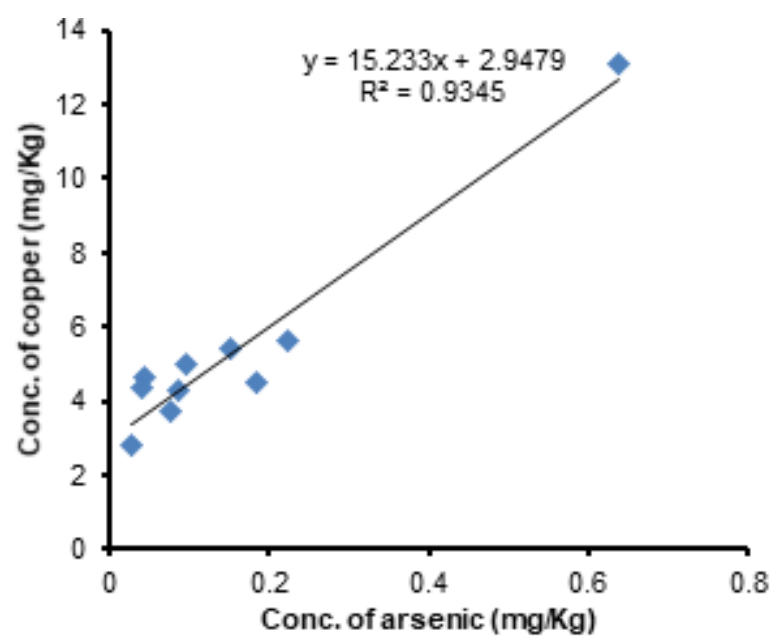

Fig 3. Correlation chart of $\mathrm{Cu}$ and $\mathrm{As}$

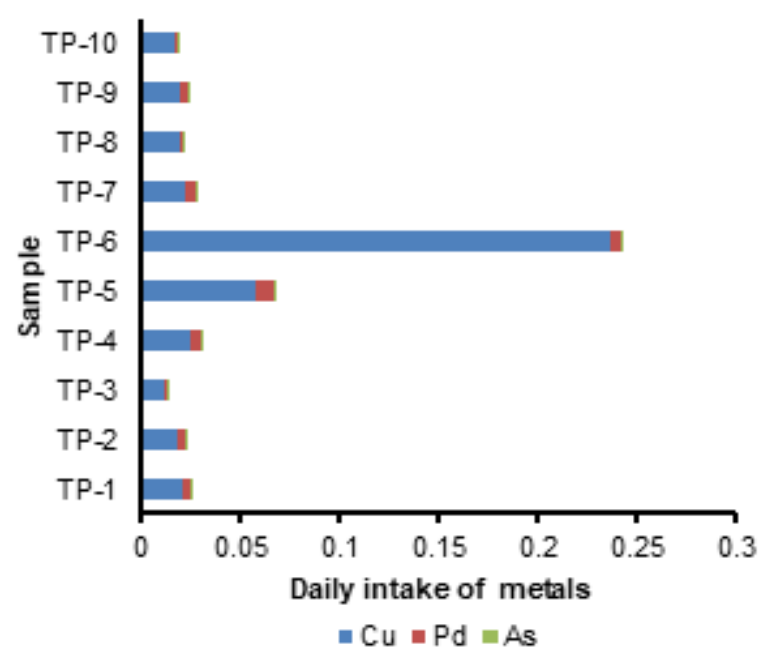

Fig 5. Daily intake of $\mathrm{Cu}, \mathrm{Pb}$ and $\mathrm{As}$ 
Table 5. Hazard Quotient (HQ) of fluoride, copper, lead, and arsenic

\begin{tabular}{|c|c|c|c|c|c|}
\hline \multirow{2}{*}{ Sample ID } & \multicolumn{4}{|c|}{ HQ } & \multirow{2}{*}{$\mathrm{HI}$} \\
\hline & $\mathrm{Cu}\left(\times 10^{-3}\right)$ & $\mathrm{Pb}\left(\times 10^{-3}\right)$ & $\operatorname{As}\left(\times 10^{-4}\right)$ & $\mathrm{F}^{-}$ & \\
\hline TP-01 & 0.51 & 0.968 & 0.633 & 0.733 & $>1$ \\
\hline TP-02 & 0.46 & 0.85 & 1.246 & 0.099 & $>1$ \\
\hline TP-03 & 0.305 & 0.297 & 0.25 & 0.0857 & $>1$ \\
\hline TP-04 & 0.619 & 1.474 & 0.2797 & 0.1046 & $>1$ \\
\hline TP-05 & 0.5918 & 1.397 & 1.683 & 0.1186 & $>1$ \\
\hline TP-06 & 1.436 & 2.332 & 9.342 & 0.0889 & $>1$ \\
\hline TP-07 & 0.52 & 1.353 & 1.078 & 0.106 & $>1$ \\
\hline TP-08 & 0.493 & 0.374 & 2.13 & 0.0994 & $>1$ \\
\hline TP-09 & 0.48 & 1.078 & 0.462 & 0.0764 & $>1$ \\
\hline TP-10 & 0.408 & 0.627 & 0.836 & 0.0588 & $>1$ \\
\hline Average value & 0.58 & 1.08 & 1.79 & 0.16 & \\
\hline
\end{tabular}

Reference Dose $\left(\mathrm{mg} / \mathrm{Kg} /\right.$ day) $6.0 \times 10^{-2}, 4.0 \times 10^{-2}, 4.0 \times$ $10^{-3}, 3.0 \times 10^{-4}$ for individual $\mathrm{F}^{-}, \mathrm{Cu}, \mathrm{Pb}$ and $\mathrm{As}$ respectively [39].

According to the WHO and USEPA, HQ and HI value should be less than one for health safety [39-40]. Average HQ of arsenic, copper, lead, and fluoride was calculated $1.79 \times 10^{-4}, 0.58 \times 10^{-3}, 1.08 \times 10^{-3}$, and 0.16 , respectively, i.e., all values were below one. Hazard Index (HI) was also found less than one. So, it revealed that metal contents in the toothpaste were safe from the risk of cancer [38]. Although this study suggests no potential health risk from these heavy metals, it must be kept in mind that these small quantities will be added to the potentially toxic metals ingested into the human body from other sources such as water, beverage, and foods, and consequently their cumulative effect may get detrimental. This can also be conceivable from the Pearson correlation which indicated the strong positive correlation $\left(\mathrm{R}^{2}\right.$ value ranged from 0.599 to 0.9345 ) among these three metals.

\section{- CONCLUSION}

Toothpaste samples exhibited good physicochemical properties except for moisture content. Fluoride content in most of the brands was higher than the standard, revealing the potential health risk, although the heavy metal related health risk is negligible. Some brands available in the market neither satisfied nor had a clear specification, which shows the availability of low-quality toothpaste in the market of Bangladesh. Substandard toothpaste causes not only a waste of money but is responsible for health hazards. So, the respective regulatory authorities should take proper measures to prevent the manufacture and marketing of low standard toothpaste in any situation in order to protect public oral health. The testing authority should also strengthen their monitoring and establish more effective analytical measures to analyze the marketed toothpaste to ensure safe public oral hygiene health. Moreover, for oral hygiene, $\mathrm{pH}$, moisture content, fluoride content and heavy metal contents in the toothpaste should be clearly specified on the packet or tube.

\section{- ACKNOWLEDGMENTS}

The authors gratefully acknowledge the support of the Department of Chemical Engineering, Jashore University of Science and Technology, Jashore and Asia Arsenic Network (AAN), Krishnabati, Pulerhat, Jashore, Bangladesh for their kind cooperation and permission to use their laboratory for the analysis to carry out this study. The authors are also thankful to Dr. Anjon Kumar Mondal, Manager, API Production, Beximco Chemical Division, Tongi, Gazipur, Bangladesh, for his critical suggestions in preparing this manuscript.

\section{- REFERENCES}

[1] Burt, B.A., 1998, Prevention policies in the light of the changed distribution of dental caries, Acta Odontol. Scand., 56 (3), 179-186. 
[2] Safra, J.E., Constantine, S.Y., and Goulk, J.E., 1998, The New Encyclopedia Britannica, 15 ${ }^{\text {th }}$ Ed., Encyclopedia Britannica, Inc., London UK, 2, 356; 7, $678 ; 10,931 ; 14,547 ; 17,293,259 ; 20,513 ; 25,55-56$, 61,$68 ; 26,846 ; 28,307$.

[3] Ivanova, M., and Christova, R., 1995, Potentiometric determination of fluorine in dentifrices of high ionic level, Anal. Lab., 4, 47-50.

[4] Carton, R.J., 2006, Review of the 2006 United States National Research Council report: Fluoride in drinking water, Fluoride, 39 (3), 163-172.

[5] Konieczka, P., Zygmunt, B., and Namieśnik, J., 2000, Effect of fluorine content in drinking water in ricity on its concentration in urine of pre-school children, Toxicol. Environ. Chem., 74 (2), 125-130.

[6] Odukudu, F.B., Ayenimo, J.G., Adekunle, A.S., Yusuff, A.M., and Mamba, B.B., 2014, Safety evaluation of heavy metal exposure from consumers, Int. J. Consum. Stud., 38 (1), 25-34.

[7] Sainio, E.L., and Kanerva, L., 1995, Contact allergens in toothpaste and a review of their hypersensitivity, Contact Dermatitis, 33 (2), 100-105.

[8] Waldbolt, G.L., 1998, The preskeletal phase of chronic fluoride intoxication, Fluoride, 31 (1), 13-20.

[9] Jordan, R.A., Markovich, L., Gaengler, P., and Zimmer, S., 2011, Total and free fluoride concentrations of African dentifrics marketed in West Africa, Oral Health Prev. Dent., 9 (1), 53-58.

[10] Oyewale, A.O., 2005, Estimation of essential inorganic constituents of commercial toothpaste, J. Sci. Ind. Res., 64 (2), 101-107.

[11] Ideriah, T.J.K., Obunwo, C.C., and Eretoru, T.D., 2016, Assessment of fluoride and heavy metals concentrations in toothpastes marketed in Port Harcourt Nigeria, Int. J. Adv. Innovative Res., 5 (5), $28-34$.

[12] Teki, K., and Bhat, R., 2013, Estimation of the components in oral care products available in Indian market - Part II: Toothpaste, Int. J. Pharm. Chem. Sci., 2 (2), 705-712.

[13] Benzian, H., Holmgren, C., Buijs, M., van Loveren, C., van der Weijden, F., and van Palenstein Helderman, W., 2012, Total and free available fluoride in toothpastes in Brunei, Cambodia, Laos, the Netherlands and Suriname, Int. Dent. J., 62 (4), 213-221.

[14] de Freitas, J.F., 1984, Fluoride stability in toothpastes, Aust. Dent. J., 29 (1), 30-35.

[15] Hashizume, L.N., de Oliveira Lima, Y.B., Kawaguchi, Y., and Cury, J.A., 2003, Fluoride availability and stability of Japanese dentifrices, $J$. Oral Sci., 45 (4), 193-199.

[16] Thakkar, V.P., Rao, A., Rajesh, G., Shenoy, R., and Pai, M., 2015, Fluoride content and labeling of toothpastes marketed in India, Community Dent. Health, 32 (3), 170-173.

[17] Ko, H.Y., Kang, S.M., Kwon, H.K., and Kim, B.I., 2015, Evaluation of fluoride bioavailability in toothpastes, J. Korean Acad. Oral Health, 39 (2), 81-87.

[18] Krishna, D.G., Al-Amri, S.H., Al-Mamari, F.S., AlSidairi, A.S., and Devi, C.K., 2015, Estimation of the essential inorganic constituents of various commercial toothpastes, Int. J. Inorg. Bioinorg. Chem., 5 (1), 14-15.

[19] Anju, T., and Aiswarya, K., 2016, Formulation and antimicrobial evaluation of toothpastes containing arginine and proline, Int. J. Adv. Pharm., Biol. Chem., 5 (2), 143-147.

[20] Prasanna, S.G.V., Abllasha, R., and Gopinath, 2016, In vitro comparison of antimicrobial efficacy of different toothpaste, J. Pharm. Sci. Res., 8 (10), 1195-1198.

[21] Rao, R.N., and Rao, T.N., 2014, Determination heavy metals in toothpastes containing tin as an ingredient, Indian J. Chem. Tehnol., 21 (4), 238-243.

[22] Mohod, C.V., and Dhote, J., 2013, Review of heavy metals in drinking water and their effect on human health, Int. J. Innovative Res., Sci. Eng. Technol., 2 (7), 2992-2996.

[23] Kawata, K., Yokoo, H., Shimazaki, R., and Okabe, S., 2007, Classification of heavy metal toxicity by human DNA microarray analysis, Environ. Sci. Technol., 41 (10), 3769-3774.

[24] Järup, L., 2003, Hazards of heavy metal contamination, Br. Med. Bull., 68 (1), 167-182. 
[25] Chien, L.C., Hung, T.C., Choang, K.Y., Yeh, C.Y., Meng, P.J., Shieh, M.J., and Han, B.C., 2002, Daily intake TBT, $\mathrm{Cu}, \mathrm{Zn}, \mathrm{Cd}$ and As for fisherman in Taiwan, Sci. Total Environ., 285 (1-3), 177-185.

[26] Food and Nutrition Board, 2004, Dietary reference intakes (DRIs): Recommended intakes for individuals, Institute of Medicine, US National Academies, Washington DC, United States.

[27] Gharaibeh, A.A., El-Rjoob, A.O., and Harb, M.K., 2010, Determination of selected heavy metals in air samples from the northern part of Jordan, Environ. Monit. Assess., 160 (1-4), 425-429.

[28] Pandey, J., Pandey, R., and Shubhashish, K., 2009, Air-borne heavy metal contamination to dietary vegetables: A case study from India, Bull. Environ. Contam. Toxicol., 83 (6), 931-936.

[29] Fernandes, C., Fontaínhas-Fernandes, A., Cabral, D., and Salgado, M.A., 2008, Heavy metals in water, sediment and tissues of Liza saliens from EsmorizParamos lagoon, Portugal, Environ. Monit. Assess., 136 (1-3), 267-275.

[30] Aguilar, C.A., Montalvo, C., Rodriguez, L., Ceron, J.G., and Ceron, R.M., 2012, American oyster (Crassostrea virginica) and sediments as a coastal zone pollution monitor by heavy metal, Int. J. Environ. Sci. Technol., 9 (4), 579-586.

[31] Salve, K.S., and Sonwane, N.S., 2015, Detection of heavy metals in cosmetics, World J. Pharm. Res., 4 (4), 1368-1372.

[32] Ayenimo, J.G., Yusuf, A.M., Adekunle, A.S., and Makinde, O.W., 2010, Heavy metal exposure from personal care products, Bull. Environ. Contam. Toxicol., 84 (1), 8-14.

[33] Bocca, B., Pino, A., Alimonti, A., and Forte, G., 2014, Toxic metals contained in cosmetics: A status report, Regul. Toxicol. Pharmacol., 68 (3), 447-467.

[34] Orisakwe, O.E., Okolo, K.O., Igweze, Z.N., Ajaezi, G.C., and Udowelle, N.A., 2016, Potential hazards of toxic metals found in toothpastes commonly used in Nigeria, Rocz. Panstw. Zakl. Hig., 67 (2), 197-204.
[35] American Public Health Association, 2005, Standard Methods for the Examination Water and Wastewater, $21^{\text {st }}$ Ed., Eds. Eaton, A.D., Clesceri, L.S., Franson, M.A.H., Rice, E.W., and Greenberg, A.E., American Public Health Association, Washington DC, United States.

[36] Bangladesh Standard and Testing Institution (BSTI), 2001, Bangladesh Standard Specification for Tooth-paste, $1^{\text {st }}$ revision, Bangladesh Standard and Testing Institution (BSTI), Dhaka, Bangladesh.

[37] Akelesh, T., Kumar, R.S., Jothi, R., Rajan, V., Arulraj, P., and Venkatnarayanan, R., 2010, Evaluation of standards of some selected cosmetic preparations, Asian J. Pharm. Res. Health Care, 2 (4), 302-306.

[38] United States Environmental Protection Agency (USEPA), 2007, Integrated risk information systemdatabase, U.S. Environmental Protection Agency, Washington DC, United States.

[39] United States Environmental Protection Agency (USEPA), Office of Water Regulations and Standards, 1989, Assessing human health risks from chemically contaminated fish and shellfish: A guidance manual, U.S. Environmental Protection Agency, Washington DC, United States.

[40] WHO, 2010, Preventing disease through healthy environments - Inadequate or excess fluoride: A major public health concern, World Health Organization, Geneva.

[41] Petersen, P.E., and Lennon M.A., 2004, Effective use of fluorides for the prevention of dental caries in the $21^{\text {st }}$ century: The WHO approach, Community Dent. Oral Epidemiol.2 32 (5), 319-321.

[42] Abou-Arab, A.A., and Abou Donia, M.A., 2000, Heavy metals in Egyptian spices and medicinal plants and the effect of processing on their leaves, $J$. Agric. Food Chem., 48 (6), 2300-2304.

[43] Wu, J., Zou, Y., Zhan, X., Lu, G., and Lai, F., 2008, Survey of heavy metal pollution in four Chinese crude drugs and their cultivated soils, Bull. Environ. Contam. Toxicol., 81 (6), 571-573. 